\title{
PERANCANGAN ARSITEKTUR SISTEM INFORMASI AKADEMIK MENGGUNAKAN THE OPEN GROUP ARSITEKTURE FRAMEWORK (TOGAF)
}

\author{
Rika Fitriana ${ }^{1)}$, Muhammad Bakri ${ }^{2)}$ \\ Sistem Informasi, Universitas Teknokrat Indonesia \\ Jl. H.ZA Pagaralam, No 9-11, Labuhanratu,Bandarlampung \\ Email : rikafitriana024@gmail.com ${ }^{1)}$, muhammadbakri@teknokrat.ac.id ${ }^{2)}$
}

\begin{abstract}
Abstrak
SMP Al-Azhar 3 Bandarlampung merupakan salah satu Sekolah Swasta yang menerapkan program unggulan yaitu Sistem pendidkan terpadu (antara sistem sekolah dan agama islam).SMP Al-Azhar Bandar lampung khususnya sistem informasi akademik, belum memiliki architecture. Infrastruktur TI seperti perangkat komputer dan jaringan dirasakan tidak cukup dalam menjawab solusi atas perubahan bisnis dan aplikasi secara cepat dan tepat, maka perlu dibuat sebuah Sistem Informasi Akademik (SIAKAD) yang terpadu untuk mendukung proses kegiatan akademik. Oleh sebab itu diperlukan suatu rancangan arsitektur yang dapat membangun dan mengelola serta mengimplementasikan architecture enterprise sistem untuk memudahkan dalam pengolahan data dan informasi menggunakan metode TOGAF. Penelitian ini menghasilkan kerangka dasar (blueprint) dalam mengembangkan sistem informasi yang terintegrasi. Tujuan dari penelitian ini adalah menghasilkan perencanaan enterprise architecture, yang dapat digunakan sebagai landasan untuk pengembangan sistem informasi akademik untuk mendukung dan menunjang strategi bisnis SMP Al Azhar 3 Bandarlampung.
\end{abstract}

Kata kunci: Architecture enterprise, togaf, sistem informasi akademik, blueprint

\section{Pendahuluan}

\subsection{Latar Belakang}

SMP Al Azhar 3 Bandarlampung merupakan salah satu Sekolah Swasta yang ada di Jl. Sultan Agung Gg.

Mawar, Kedaton, Kec, Kedaton, Kota Bandar Lampung Prov. Lampung yang menerapkan program unggulan yaitu Sistem pendidkan terpadu (antara sistem sekolah dan agama islam).

Jika ditinjau dari struktur organisasi, Pada SMP Al Azhar 3 Bandarlampung memiliki banyak bidang yang membawahi urusan-urusan seperi pengelolaan program akademik, pengelolaan data siswa, pengelolaan data guru, managemen keuangan atau administrasi dan sumber daya manusia (SDM). Banyaknya bidang tersebut mengakibatkan tingkat kompleksitas data dan informasi yang tinggi pada SMP Al Azhar 3 Bandarlampung, sehinga dapat memunculkan resiko kesalahan dalam manajemen data. Oleh karena itu dengan adanya dukungan teknologi informasi (TI) berupa sistem informasi yang di dasari faktor managerial SMP Al Azhar 3 Bandarlampung.

Pada SMP Al Azhar 3 Bandarlampung khususnya sistem informasi akademik, belum memiliki architecture. Infrastruktur TI seperti perangkat komputer dan jaringan dirasakan tidak cukup dalam menjawab solusi atas perubahan bisnis dan aplikasi secara cepat dan tepat, maka perlu dibuat sebuah Sistem Informasi Akademik (SIAKAD) yang terpadu untuk mendukung proses kegiatan akademik. Namun dalam pelaksanaannya, penerapan SIAKAD tidak selalu berjalan lancar dan masih terdapat beberapa kendala, sehingga pemanfaatan SI saat ini hanya untuk memenuhi suatu kebutuhan terhadap bagian atau divisi tertentu, menyebabkan pertukaran informasi dan kebutuhan mengenai data akan sulit dipenuhi dalam waktu yang cepat dan tepat.

Kondisi saat ini SMP Al Azhar 3 Bandarlampung belum memiliki arsitektur sistem informasi sekolah yang sesuai dengan kebutuhan dan tujuan pihak sekolah. Penyebab sebelumnya memang dari pihak sekolah belum fokus terhadap proses pengembangan sistem informasi. Dari permasalahan tersebut maka diperlukan sebuah paradigma dalam merencanakan, merancang, dan mengelola sistem informasi yang disebut dengan Enterprise Architecture. Sehingga ketersediaan data yang terformat baik, dalam satu sumber data yang terkelola dengan baik akan terpenuhi (Falahah and Rosmala, 2010). EA (Enterprise Architecture) pada dasarnya adalah strategi pemanfaatan IT dan integrasi antara pengembangan bisnis dengan pengembangan IT. EA mengambarkan rencana untuk mengembangkan sebuah sistem atau sekumpulan sistem.

Berbagai macam paradigma dan metode yang dapat digunakan dalam perancangan arsitektur enterprise seperti Zachman Framework, EAP, EAS, BEAM, TOGAF ADM, GEAF, dan lainnya. Dalam penelitian yang dilakukan oleh (Setiawan, 2009) serta (Lusa and Sensuse, 2011) TOGAF merupakan framework yang paling cocok untuk enterprise yang masih belum mempunyai blueprint tentang pengembangan EA. Pemilihan EA yang tepat dengan kondisi sebuah organisasi akan mempercepat dan menyederhanakan pengembangan arsitektur. Berbagai macam EA yang ada masing-masing memiliki kelebihan dan kelemahan, 
tergantung pada karakteristik enterprise itu sendiri.

The Open Group Architecture framework (TOGAF) adalah suatu framework untuk arsitektur perusahaan yang memberikan pendekatan yang komprehensif untuk perencanaan, perancangan, dan pelaksanaan arsitektur informasiperusahaan. TOGAF memberikan gambaran metode yang rinci bagaimana membangun dan mengelola serta mengiplementasikan frameworkdan sistem informasi yang digunakan untuk menggambar sebuah model pengembangan arsitektur enterprise sehingga dapat dijadikan rekomendasi dalam pengembangan sistem yang terintegrasi dan bernilai, selain itu kelebihan framework TOGAF adalah acuannya lebih ke object oriented, sifatnya yang fleksibel, dan open source, sehingga banyak digunakan pada berbagai bidang seperti perbankan, industri manufaktur dan juga pendidikan (Open Group, 2009).

Dari permasalahan tersebut maka diperlukan suatu rancangan arsitektur yang dapat membangun dan mengelola serta menginplementasikan enterprise architecture sistem untuk memudahkan dalam pegolahan data dan informasi seperti Data Arsitektur yang mendefinisikan berbagai macam data yang mendukung fungsi organisasi yang didefinisikan didalam proses kerja. Output dari penelitian ini adalah menghasilkan kerangka dasar (blueprint) dalam mengembangkan sistem informasi yang terintegrasi untuk mendukung kebutuhan sekolah. Tujuan dari penelitian ini adalah menghasilkan perencanaan enterprise architecture, yang dapat digunakan sebagai landasan untuk pengembangan sistem informasi akademik untuk mendukung dan menunjang strategi bisnis SMP Al Azhar 3 Bandarlampung.

\subsection{Rumusan Masalah}

Dengan melihat latar belkang diatas maka, dapat diidentifikasi beberapa masalah yang perlu diperhatikan yaitu::

1. Bagaimana menyusun sebuah blue print atau gambaran rencana secara jelas untuk penggunaan informsi dalam mendukung aktifitas bisnis di SMP Al-Azhar 3 Bandarlampung..

2. Bagaimana merancang sistem informasi sekolah terpadu yang dapat digunakan sesuai kebutuhan SMP Al-Azhar 3 Bandarlampung.

3. Bagaimana merancang arsitektur bisnis, arsitektur sistem informasi, opportunities and solutions dan migrasi planning di SMP Al-Azhar 3 Bandarlampung.

\subsection{Batasan Masalah}

Batasan masalah pada penelitian ini adalah sebagai berikut:

1. Hanya membahas tentang perancangan Arsitektur pada SMP Al Azhar 3 Bandarlampung.

2. Tidak membahas jenis aplikasi yang digunakan pada komponen arsitektur.
3. Arsitektur berdasarkan kebutuhan pada SMP Al Azhar 3 Bandarlampung

\subsection{Tujuan Penelitian}

Adapun tujuan penelitian yang dilakukan yaitu:

1. Merancang arsitektur sistem informasi yang sesuai dengan kebutuhan dan tujuan strategis SMP AlAzhar 3 Bandarlampung.

2. Dengan adanya arsitektur sistem informasi sekolah ini dapat menyajikan informasi yang dibutuhkan oleh berbagai pihak dengan lebih cepat dan akurat.

3. Dapat membantu dalam proses integrasi sistem informasi yang sudah ada dan dapat mendukung sistem informasi sekolah, sehingga menjadi suatu sistem yang terintegrasi secara menyeluruh

\subsection{Manfaat Penelitian}

Adapun manfaat penelitian yang dilakukan yaitu:

1. Hasil penelitian ini berguna untuk masyarakat yang ingin menginplementasikan arsitektur ini kedalam bentuk sistem informasi akademik SMP Al Azhar 3 Bandarlampung.

2. Dari penerapan arsitektur ini di harapkan penggunaan sistem informasi akademik yang dapat di integerasikan pada Sekolah SMP Al Azhar 3 Bandarlampung.

\section{Pembahasan}

2.1

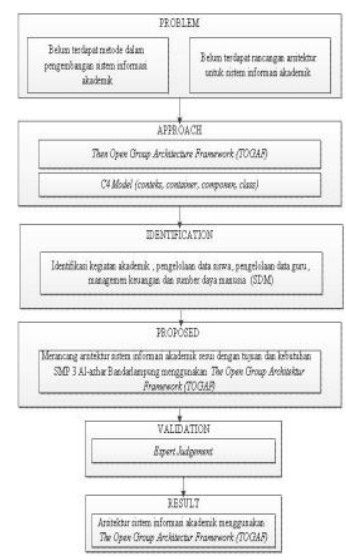

Kerangka PemikiranGambar 2 Kerangka Pemikiran

Gambar 2 Kerangka Pemikiran

1. Problem (Permasalahan)

Belum terdapat metode dalam membangun arsitektur sistem informasi dan rancangan arsitektur belum tersedia.

2. Approach (Pendekatan)

Pendektan terhadap masalah yang dilakukan pada penelitian ini dalam merancang arsitektur sistem informasi akademik, framework yang dipakai adalah The Open Group Architecture Framework (TOGAF) dengan metodologi Architecture Development Method (ADM) untuk membuat blueprint Sistem Informasi Akademik. 
3. Identification (Identifikasi)

Identifikasi dalam tahapan ini adalah identifikasi yang berkaitan dengan kegiatan akademik, administrasi, manajemen keuangan, dan sumber daya manusia (SDM).

4. $\quad$ Proposed (Usulan)

Usulan yang akan diajukan dalam tahapan penelitian ini adalah membuat perancangan arsitektur sistem informasi akademik menggunakan The Open Group Architecture Framework (TOGAF)

5. Validation (Validasi)

Pegujian dilakukan menggunakan metode Expert Judgement atau pertimbangan ahli. Pengujian ini dilakukan untuk mendapatkan hasil yang diinginkan dari para ahli.

6. Result (Hasil)

Penelitian ini menghasilkan perencanaan rancangan arsitektur enterprise yang dapat digunakan untuk pengembangan sistem informasi akademik menggunakan framework TOGAF.

\subsection{Tahapan Penelitian}

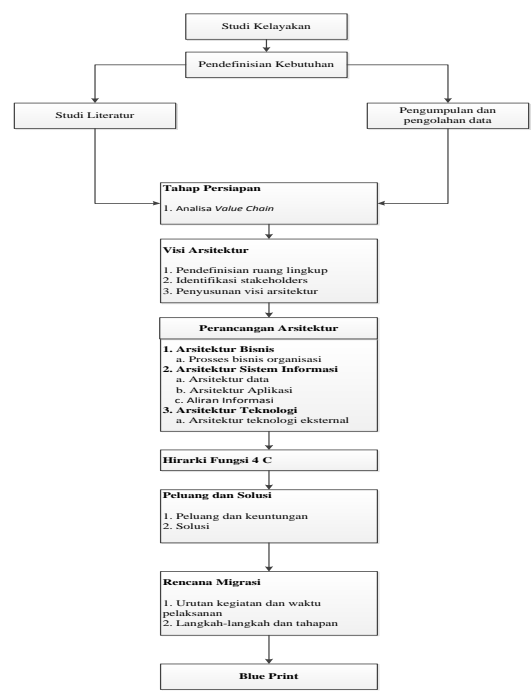

Gambar 3 Tahapan Penelitian

\subsection{Persiapan (Preliminary)}

Tahapan ini dilakukan untuk mengidentifikasi persiapan komponen-komponen yang terkait penelitian dengan melakukan observasi dan studi dokumen yang digunakan dalam proses kegiatan yang berhubungan dengan sistem di lingkungan SMP Al-azhar 3 Bandarlampung.

\subsection{Visi Arsitektur}

Langkah-langkah dalam visi arsitektur adalah mencakup pendefinisian ruang lingkup, identifikasi stakeholders, dan penyusunan visi arsitektur.

a. Pendefinisian Ruang Lingkup

Pendefinisian ruang lingkup adalah sebagai berikut :

1. Aktivitas Utama
a. Pengelolaan program akademik
b. Pengelolaan data siswa
c. Pengelolaan data guru

2. Aktifitas pendukung

a. Manajemen keuangan

b. Manajemen sumber daya manusia

b. Identifikasi Stakeholders

Berikut stakeholder yang berhubungan dengan sistem informasi akademik di SMP 3 Al-Azhar Badarlampung yaitu : Direktorat Pembinaan SMP dan diknas, Orang tua/wali, Peserta didik, Pendidik, Tenaga non kependidikan. Mekanisme hubungan antara sistem informasi yang akan dibangun dengan stakeholder dapat dilihat pada Tabel 1

Tabel 1 Hubungan Sistem Informasi Dengan

Stakeholders

\begin{tabular}{|l|l|l|}
\hline \multicolumn{1}{|c|}{ No } & \multicolumn{1}{|c|}{ Peran } & \multicolumn{1}{|c|}{ Tanggung jawab } \\
\hline 1 & Kepala sekolah & $\begin{array}{l}\text { Sebagai pengawas dan } \\
\text { penanggung jawab }\end{array}$ \\
\hline 2 & Peseta didik & $\begin{array}{l}\text { Pemberian layanan } \\
\text { administrasi peserta } \\
\text { didik }\end{array}$ \\
\hline 3 & Pendidik & $\begin{array}{l}\text { Sebagai pengguna } \\
\text { jasa institusi internal }\end{array}$ \\
\hline 4 & $\begin{array}{l}\text { Tenaga non } \\
\text { pendidikan (staff) }\end{array}$ & $\begin{array}{l}\text { Sebagai pengguna } \\
\text { jasa institusi internal }\end{array}$ \\
\hline
\end{tabular}

\subsubsection{Penyusunan Visi Arsitektur}

Visi arsitektur sistem informasi sekolah pada SMP 3 AlAzharBadarlampung adalah sebagai berikut :

"Menyediakan layanan yang terintegrasi pada tahun 2025".

\subsubsection{Output Visi Arsitektur}

A. Ruang Lingkup dan Konstrain

1. Aktifitas Utama

a. Pengelolaan program akademik

b. Pengelolaan data guru

c. Pengelolaan data siswa

2. Aktifitas Pendukung

a. Manajemen keuangan

b. Manajemen sumber daya manusia

\subsubsection{Rencana Pengerjaan}

Waktu pengerjaan pada sistem ini dimulai pada tahun 2018-2020,dilakukan selama 3 tahun.Rencana yang dilakukan pada sistem ini yaitu:

1. Pengelolaan program akademik

Meliputi penyusunan kalender akademik, penetuan pengajar, pembuatan jadwal pelajaran, kurikulum pendidikan. Target pengerjaan sistem dimulai pada tahun 2018-2019.

2. Pengelolaan data guru

Meliputi data nama guru, NIP, alamat dan guru bidang studi. Target pengerjaan sistem dimulai pada tahun 2018-2019.

3. Pengelolaan data siswa Meliputi data nama siswa dan NIS siswa. Target pengerjaan sistem 2018-2019.

4. Manajemen keuangan 
Menetukan perencanaan anggaran, penetapan anggaran, administrasi pembayaran siswa, laporan keuangan. Target pengerjaan sistem 2018-2020.

5. Manajemen sumber daya manusia Meliputi perencanaan SDM, perekrutan SDM, pembinaan dan pengembangan SDM. Targer pengerjaan sistem 2019-2020.

\subsubsection{Stakeholders Sistem Informasi Akademik} Tabel 2 Hubungan Stakeholder

\begin{tabular}{|l|l|l|}
\hline No & \multicolumn{1}{|c|}{ Peran } & \multicolumn{1}{|c|}{ Tanggung jawab } \\
\hline 1 & Kepala sekolah & $\begin{array}{l}\text { Sebagai pengawas dan } \\
\text { penanggung jawab }\end{array}$ \\
\hline 2 & Peseta didik & $\begin{array}{l}\text { Pemberian layanan } \\
\text { administrasi peserta } \\
\text { didik }\end{array}$ \\
\hline 3 & Pendidik & $\begin{array}{l}\text { Sebagai pengguna } \\
\text { jasa institusi internal }\end{array}$ \\
\hline 4 & $\begin{array}{l}\text { Tenaga non } \\
\text { pendidikan (staff) }\end{array}$ & $\begin{array}{l}\text { Sebagai pengguna } \\
\text { jasa institusi internal }\end{array}$ \\
\hline
\end{tabular}

\subsubsection{Resiko dan Mitigasi}

Komponen mitigasi resiko berdasarkan ISO 31000:

1. Arsitektur manajemen resiko

2. Strategi majemen resiko

3. Protokol majemen resiko

\subsubsection{Performa Sistem}

Standar performa yang akan digunakan pada sistem ini adalah ISO 25010.

Berikut komponen ISO 25010 :
1. Funcional suitability
2. performance Efficiency
3. Compatibility
4. Usability.
5. Realiability
6. Keamanan .
7. Maintainability.
8. Portabilitas

\subsection{Perancangan Arsitektur Bisnis \\ 2.3.1 Arsitektur Bisnis}

Arsitektur fungsi bisnis merupakan aktifitas-aktifitas yang terkait proses bisnis utama meliputi stakeholder dan proses bisnis, pada proses bisnis terdapat beberapa fungsi utama dan fungsi pendukung sistem akademik.

\subsubsection{Struktur Organisasi}

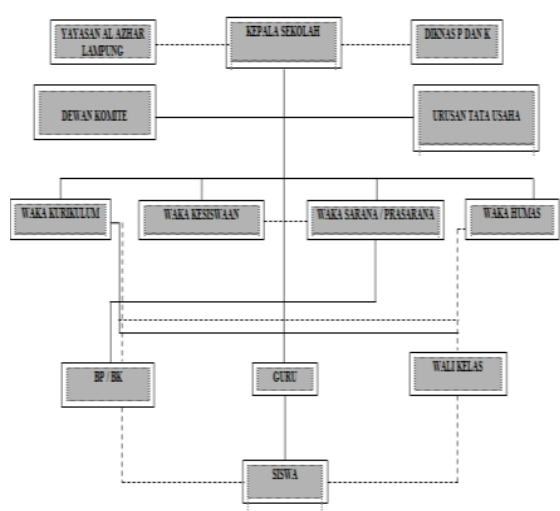

Gambar 4. Struktur Organisasi

\subsubsection{Layanan Bisnis}

Tabel 3 Layanan Bisnis

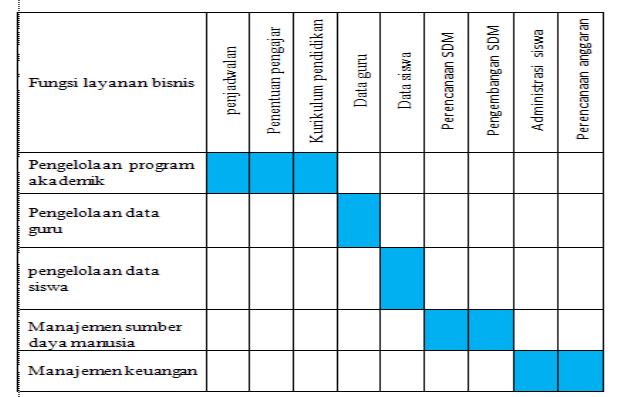

\subsubsection{Proses Bisnis}

Proses bisnis yang dilakukan terdapat dua bagian aktivitas yaitu aktivitas utama dan aktivitas pendukung.

1. Aktifitas Utama

a. Program akademik

Proses ini berfokus pada pengelolaan akademik yang menjadi aktifitas paling utama di SMP Al-Azhar 3 Bandarlampung.

b. Pengelolaan data siswa

Pengelolaan data siswa meliputi nama siswa, NIS, NISN, jenis kelamin, kelas atau jurusan, nama orang tua, alamat dan nomor telepon.

c. Pengelolaan data guru

Pengelolaan data guru meliputi manajemen biodata guru dan karyawan, data keluarga, riwayat pendidikan.

2. Aktifitas pendukung

a. Manajemen keuangan

manajemen keuangan merupakan tindakan pengurusan atau ketatausahaan keuangan yang meliputi :

1. Perencanaan anggaran

2. Penetapan anggran

3. Administrasi pembayaran siswa

4. Laporan pertanggung jawaban keuangan

5. Pembelanjaan organisasi

b. Manajemen sumber daya manusia

Merupakan aktifitas yang berkaitan dengan pemenuhan kebutuhan sumber daya manusia serta alokasi sumber daya manusia sesuai dengan tugas masing-masing khususnya pada aktivitas operasional akademik yang meliputi :
a. Perencanaan SDM
b. Perekrutan SDM
c. Pembinaan dan Pengembangan SDM

\subsection{Kolerasi Organisasi dan Fungsi}

Hubungan dan fungsi bisnis dapat dilihat pada tabel berikut: 
Tabel 4 Hubungan Fungsi Bisnis

\begin{tabular}{|c|r|r|r|r|}
\hline \multirow{2}{*}{ Peran } & \multicolumn{3}{|c|}{ Tanggung Jawab } \\
\cline { 2 - 5 } & 产 & 产 & 言 & 灾 \\
\hline Kapsla sekolah & & & & \\
\hline Peserta didik & & & & \\
\hline Pendidik & & & & \\
\hline staff & & & & \\
\hline
\end{tabular}

Ket : Pengawas Dan Penanggung Jawab (PDBJ) Pemberian Layanan Administrasi Peserta Didik (PLAPD)

Sebagai pengguna jasa institusi internal (PJII) Sebagai pengguna jasa institusi internal (PJII)

\subsection{Arsitektur Sistem Informasi}

Arsitektur sistem informasi dibangun untuk mengembangkan arsitektur target untuk data aplikasi dan menentukan tipe dan sumber data, berikut adalah bagian dari arsitektur sistem informasi.

\subsubsection{Arsitektur Data}

Perancangan arsitektur data merupakan kebutuhan data yang akan digunakan pada arsitektur aplikasi, berdasarkan proses bisnis yang dirancang pada value chain terdapat beberapa entitas yang telah didefinisikasn untuk mengetahuibahwa kebutuhan arsitektur data yang dirancang harus sesuai dengan proses bisnis akademik. Arsitektur data yang digunakan sebagai berikut :

1. Registrasi Peserta Didik Baru (PPDB)

2. Proses Belajar Mengajar (PBM)

3. Penglepasan Akademik (PA)

4. Manajemen Tata Usaha (MTU)

5. Manajemen Keuangan (MK

Tabel 5 Daftar Rancangan Aplikasi

\begin{tabular}{|l|l|c|}
\hline \multicolumn{1}{|c|}{$\begin{array}{c}\text { Kode } \\
\text { Aplikasi }\end{array}$} & \multicolumn{1}{|c|}{ Nama Aplikasi } & Tersedia \\
\hline ARSB_1 & Aplikasi Registrasi Siswa Baru & Tidak \\
ARSB_2 & Aplikasi Heregistrasi & Tidak \\
\hline PBM_1 & Aplikasi Operasional & Tidak \\
PBM_2 & Akademik & Tidak \\
PBM_3 & Aplikasi Jadwal Pelaksanaan & Tidak \\
PBM_4 & Ujian & Tidak \\
& Aplikasi Pengolahan Nilai & \\
& Aplikasi Sistem Info Akademik & \\
\hline PA_1 & Aplikasi Penentuan Kelulusan & Tidak \\
PA_2 & Aplikasi Pembuatan Ijazah & Tidak \\
PA_3 & Aplikasi Pelacakan Alumni & Tidak \\
\hline MTU_1 & Aplikasi Pengelolaan Data & Tidak \\
MTU_2 & Guru & Tidak \\
MTU_3 & Aplikasi Pengelolaan Data & Tidak \\
\hline
\end{tabular}

\begin{tabular}{|l|l|l|}
\hline & Siswa & \\
& Aplikasi Rencana Kegiatan & \\
\hline MK_1 & Aplikasi Adminitrasi & Tidak \\
MK_2 & Aplikasi Penggajian & Tidak \\
MK_3 & Aplikasi Anggaran Sekolah & Tidak \\
\hline
\end{tabular}

\subsection{Aliran Informasi}

Aliran informasi yang saling terintegrasi antara aplikasi satu dengan yang lain dapat didefinisikan sebagai gambaran aliran informasi yang sampai ke aplikasi dan diteruskan ke aplikasi yang selanjutnya sehingga membentuk aliran informasi yang sesuai kebutuhan akademik, berikut adalah aliran informasi antar aplikasi :

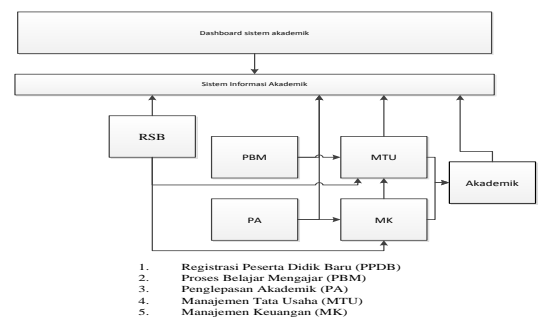

Gambar 8. Aliran Informasi

\subsection{Hirarki Fungsi}

Pemodelan hirarki untuk penggambaran atau memvisualisasikan perangkat lunak dengan 4 komponen yaitu C4 (Conteks, Container, Componen and Class), berikut merupakan bagian hirarki model $\mathrm{C} 4$ :

1. Diagram Conteks

Diagram konteks merupakan tahap awal untuk membuat diagram dan mendokumentasikan perangkat lunak terkait dengan pengembangan sistem informasi siakad menggunakan TOGAF.

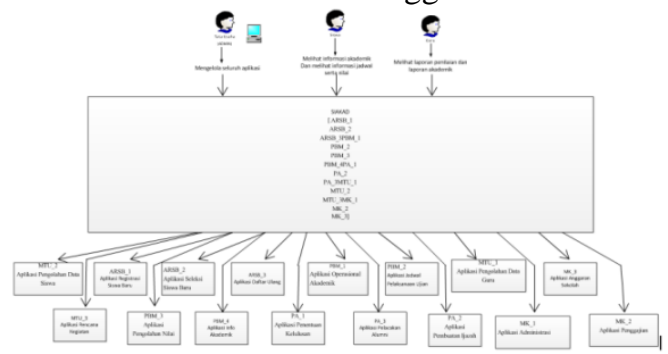

Gambar 9. Conteks diagram

2. Diagram Container

Diagram kontainer merupakan penggambaran bentuk tingkat tertinggi perangkat lunak dan bagaimana tanggung jawabnya.

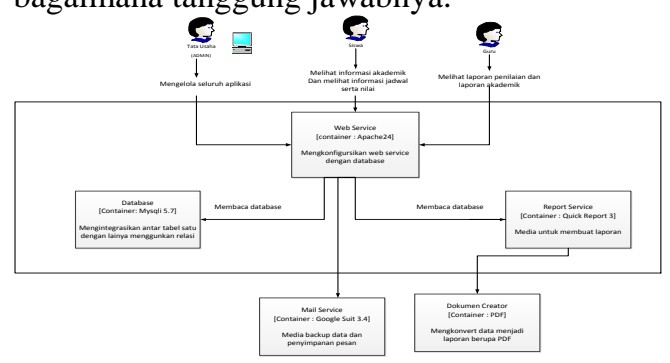

Gambar 10. Container diagram

3. Diagram Component

Diagram komponen merupakan penggambaran untuk menunjukan bagaimana wadah terdiri dari 
sejumlah komponen. Berikut adalah diagram komponen sistem informasi akademik:

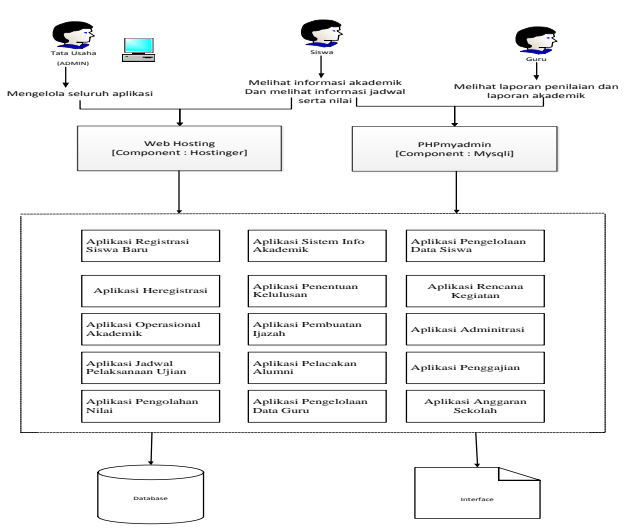

Gambar 11. Container Component

\subsection{Kesimpulan}

\section{Kesimpulan}

Berdasarkan hasil analisis proses bisnis dan pemodelan dengan arsitektur enterprise SMP Al Azhar 3 Bandarlampung maka dapat diambil kesimpulan sebagai berikut:

1. Perancangan sistem informasi akademik menggunakan TOGAF memberikan penggunaan SI dan TI yang saling terintegrasi antar bagian.

2. Analisis yang dilakukan pada proses bisnis berupa value chain untuk mengetahui aktifitas utama dan aktifitas pendukung. Dengan mengetahui kegiatan utama pada proses bisnis awal merupakan tahap kerangka kerja awal TOGAF sebagai usulan perancangan arsitektur enterprise.

3. Perancangan sistem informasi akademik menggunakan TOGAF menghasilkan rancangan yang sesuai dengan kebutuhan akademik SMP Al Azhar 3 Bandarlampung yaitu daftar aplikasi yang akan disiapkan pada tahap pengembangan sistem, sehoingga arsitektur enterprise yang dibangun sebagai acuan bagian sekolah untuk menerapkan siakad dengan menggunakan TOGAF.

\subsection{Saran}

Berdasarkan pembahasan arsitektur TOGAF pada SMP Al-Azhar 3 Bandarlampung adapun saran adalah diharapkan arsitektur akademik dengan model TOGAF ADM dapat diimplementasikan sehingga dapat membantu pelaksanaan dan pengorganisasian akademik dengan baik sesuai dengan model TOGAF ADM dan konsep arsitektur enterprise.

\section{Daftar Pustaka}

Agarina, M. (2015) 'Pemanfaatan Framework TOGAF Untuk Perencanaan Sistem Informasi Manajemen Aset Dan Logistik Di Ibi Darmajaya Bandar Lampung (Studi Kasus : Ibi Darmajaya Bandar Lampung)', Jurnal Informatika, 15(2), pp. 175-187.

Brown, S. (2012) The C4 model for software architecture, The C4 model for software architecture.

Available

at:

https://c4model.com/.

Falahah and Rosmala, D. (2010) 'Penerapan Framework Zachman Pada Arsitektur Pengelolaan Data Operasional (Studi Kasus SBU Aircraft Services, PT. Dirgantara Indonesia)', Seminar Nasional Aplikasi Teknologi Informasi, 2010(Snati), pp. 96-98.

Ginanjar, A. D. and Hanafi, R. (2015) 'Perancangan Data Architecture Untuk Fungsi Akademik Pada Institut Xyz Menggunakan Framework Togaf Adm Studi Kasus Sistem Informasi Akademik ( Siakad ) Design Of Data Architecture For Academic Functions At Institut Xyz Using Togaf Adm Framework Case Study', 2(2), pp. 5400-5407.

Lusa, S. and Sensuse, D. I. (2011) 'Kajian Perkembangan Dan Usulan Perancangan Enterprise Architecture Framework', Seminar Nasional Aplikasi Teknologi Informasi, 2011(Snati), pp. 17-18.

Meyer, M. A. and Booker, J. M. (2001) Eliciting and analyzing expert judgment : a practical guide. Society for Industrial and Applied Mathematics and American Statistical Association.

Muhammad, F. Et Al. (2017) 'Perancangan Enterprise Architecture Sistem Penjualan Dengan Metode Togaf Adm Pada Dark', Pp. 1-13.

Open Group (2009) The Open Grup Architecture Framework. Available at: http://www.opengroup.org (Accessed: 1 September 2018).

Rizky, N. and Firmansyah, A. F. (2017) 'Perencanaan Arsitektur Enterprise Menggunakan Togaf Adm Versi 9 ( Studi Kasus : Bimbel Salemba Group )', 10(1), pp. 11-20.

Setiawan, E. B. (2009) 'Pemilihan EA Framework', Seminar Nasional Aplikasi Teknologi Informasi (SNATI), 2009(SNATI), pp. 114$119 . \quad$ Available at: journal.uii.ac.id/index.php/Snati/article/view/.. .$/ 979 ?$

Wikata, E. R., Setiawan, N. Y. and Mursityo, Y. T. (2018) 'Perencanaan Sistem Penjualan Menggunakan Togaf Architecture Development Method ( TOGAF-ADM ) Studi Pada PT . Millennium Pharmacon International Tbk Cabang Malang', 2(9), pp. 2589-2598.

Yunis, R. and Surendro, K. (2009) 'Perancangan Model Enterprise Architecture Dengan Togaf', ResearchGate, 2009(Snati 2009), pp. 25-31. 